\title{
PENDIDIKAN KARAKTER \\ SEBAGAI BAGIAN DARI REVOLUSI MENTAL MENURUT PANDANGAN GEREJA KATOLIK
}

Oleh: Herman Embuiru Wetu

\begin{abstract}
Abstrak:
Atikel ini bertujuan untuk melihat pendidikan karakter dari sudut pandang Gereja Katolik. Di sini, $\triangle$ penulis lebih banyak memberikan masukkan dari aspek atau pandangan Katolik, tentang Pendidikan 1 Karakter yang menjadi sebuah harapan primadona bagi bangsa dan Negara Indonesia sekarang ini. Tulisan yang ditawarkan ini, setelah melihat, membaca dan mendengarkan serta mencoba mendampingi para guru, (kepala sekolah, guru), pengawas pendidikan, orang tua/wali, dan komite sekolah di wilayah Kabupaten Ende, yang dituangkan dalam Pendidikan Nilai atau Budi Pekerti menurut pengertian klasik dari ajaran Gereja Katolik. Pendidikan Nilai inilah yang menjadi bahan pendampingan kepada siswa/i SD, SMP, SMA pada lembaga pendidikan Katolik.
\end{abstract}

Kata Kunci: Karakter, Pendidikan Karakter, Revolusi, Revolusi Mental, Pendidikan Katolik.

\section{Pendahuluan}

Ada tiga term yang perlu dijelaskan pada bagian awal ini yakni: term pendidikan, karakter, revolusi mental. Pendidikan adalah proses pengubahan sikap dan tata laku seseorang atau kelompok orang dalam usaha mendewasakan manusia melalui upaya pengajaran dan latihan, proses, perbuatan, cara mendidik. Karakter adalah sifat-sifat kejiwaan, akhlak, budi pekerti yang membedakan seseorang dengan yang lain, tabiat, watak. Revolusi adalah perubahaan ketatanegaraan (pemerintahan atau keadaan sosial) yang dilakukan dengan kekerasan (seperti perlawanan bersenjata). Revolusi dapat juga berarti perubahan yang cukup mendasar di suatu bidang. Mental adalah hal yang menyangkut bathin dan watak manusia, yang bukan bersifat badan atau tenaga (Kamus besar Bahasa Indonesia, Departemen Pendidikan dan Kebudayaan - Balai Pustaka- Jakarta, 1988). Ketiga terminolgi ini sulit dipisahkan dalam kerangka pembangunan Sumber Daya Manusia Indonesia yang berkarakter.

Pengertian dasar di atas sebenarnya mau mengatakan bahwa pendidikan karakter sebagai bagian dari revolusi mental, dimengerti sebagai proses pengubahan sikap dan tata laku, baik rohani (spiritual) maupun jasmani (badaniah) sesorang atau kelompok orang dalam hal/demi mendewasakan manusia melalui upaya pengajaran dan latihan, dalam memproseskan, perbuatan, atau cara mendidik dalam hal sifat-sifat kejiwaan, akhlak, budi pekerti, watak, tabiat yang membedakan seseorang dengan yang lain, dan yang dibangun atau dilakukan dengan cara perubahan yang mendasar pada seseorang atau kelompok manusia.

Karena itu, amat dibutuhkan proses pendidikan diri manusia secara perorangan atau kelompok seutuhnya (sifat, tabiat, fisik dan phsikis) dengan cara yang radikal/cepat untuk mencapai tata laku, kepribadian manusia yang utuh, dalam hal iman/kepercayaan, kepribadian, kemanusiaan/ kemasyarakatan sosial dan bernegara.

Pengertian Karakter, Karakter Bangsa, dan Pembangunan Karakter Bangsa:

Karakter 
Karakter adalah nilai-nilai yang khas-baik (tahu nilai kebaikan, mau berbuat baik, nyata berkehidupan baik, dan berdampak baik terhadap lingkungan) yang terpateri dalam diri dan terejawantahkan dalam perilaku. Karakter secara koheren memancar dari hasil olah pikir, olah hati, olah raga, serta olah rasa dan karsa seseorang atau sekelompok orang. Karakter merupakan ciri khas seseorang atau sekelompok orang yang mengandung nilai, kemampuan, kapasitas moral, dan ketegaran dalam menghadapi kesulitan dan tantangan.

Karakter Bangsa

Karakter bangsa adalah kualitas perilaku kolektif kebangsaan yang khas-baik yang tercermin dalam kesadaran, pemahaman, rasa, karsa, dan perilaku berbangsa dan bernegara sebagai hasil olah pikir, olah hati, olah rasa dan karsa, serta olah raga seseorang atau sekelompok orang. Karakter bangsa Indonesia akan menentukan perilaku kolektif kebangsaan Indonesia yang khas-baik yang tercermin dalam kesadaran, pemahaman, rasa, karsa, dan perilaku berbangsa dan bernegara Indonesia yang berdasarkan nilai-nilai Pancasila, norma UUD 1945, keberagaman dengan prinsip Bhinneka Tunggal Ika, dan komitmen terhadap NKRI.

Pembangunan Karakter Bangsa

Pembangunan Karakter Bangsa adalah upaya kolektif-sistemik suatu negara kebangsaan untuk mewujudkan kehidupan berbangsa dan bernegara yang sesuai dengan dasar dan ideologi, konstitusi, haluan negara, serta potensi kolektifnya dalam konteks kehidupan nasional, regional, dan global yang berkeadaban untuk membentuk bangsa yang tangguh, kompetitif, berakhlak mulia, bermoral, bertoleran, bergotong royong, patriotik, dinamis, berbudaya, dan berorientasi IPTEK berdasarkan Pancasila dan dijiwai oleh iman dan takwa kepada Tuhan Yang Maha Esa.

Pembangunan karakter bangsa dilakukan secara koheren melalui proses sosialisasi, pendidikan dan pembelajaran, pemberdayaan, pembudayaan, dan kerja sama seluruh komponen bangsa dan negara (Kebijakan Nasional Pembangunan Karakter Bangsa, hal 7-8 dari 41 hal. Teks Manual 2013). Hal ini sangat dimungkinkan karena dalam pemikiran bangsa ini, sifat, tabiat, (kehidupan moral, iman/agama, dan kemasyarakatan/bernegara) sudah terkikis, atau ditinggalkan bahkan tidak dihiraukan lagi oleh manusia Indonesia, baik secara perorangan, maupun kelompok. Maka bangsa ini membutuhkan momen refleksi dan saat untuk membangun kembali manusia dalam hal sikap, kepribadian, watak yang baik dan benar dan semangat kebangsaan yang utuh dan tidak terpecah. Pertanyaan kita ini benar? Atau pandangan kita ini benar? Baiklah Penulis coba menawarkan buah pikiran berikut ini.

\section{Pandangan Gereja Katolik dalam Reksa Pastoralnya di Indonesia.}

Kehadiran Pendidikan Katolik (baca:lembaga formal katolik) di Indonesia pertama-tama disadari sebagai anugerah, rahmat dari Tuhan sendiri. Secara sosial budaya Indonesia, kehadiran pendidikan katolik sejak awal diterima oleh masyarakat Indonesia. Mengingat usianya relatif cukup panjang, puluhan bahkan ratusan tahun maka tidak mengherankan kalau pendidikan katolik telah memiliki bentuk yang mengakar dan sulit untuk dijelaskan. Para pewaris saat kini bertugas untuk melestarikan dan mengembangkan warisan semangat pendiri tersebut secara kontekstual. Hal ini merupakan tugas yang amat berat.

Menyadari bahwa dalam mendampingi kaum muda, baik perorangan maupun kelompok persoalannya semakin kompleks, mengandung unsur ketidakpastian dan selalu berada pada situasi yang cepat berubah, maka para pewaris Pendidikan Katolik harus berani mengadakan redefinisi, reposisi, reorganisasi, restrukturisasi dan revitalisasi serta reaktualisasi karya kerasulan pendidikan termasuk dalam hal pendidikan karakter. Agar tidak 
terjebak pada manajemen praktis dan politisasi pendidikan, maka Pendidikan Katolik terpanggil untuk mengadakan:"Reformasi dan Revitalisasi serta Redinamisasi Reksa Pastoral Pendidikan untuk Membangun Manusia Indonesia yang Bermartabat". Inilah salah satu makna yang ditawarkan dalam hal mendidik, membangun manusia Indonesia seutuhnya. Di sana secara singkat mau mengatakan peran pendidikan katolik yang ada di Indonesia sesuai dengan amanat dari warisan agamanya dan sesuai dengan pesan Guru Ilahinya. Dia berusaha untuk mendidik dan membangun manusia seutuhnya dalam hal kepribadian, watak, tabiat, dan fisik yang sungguh utuh, sehingga sering muncul semboyan: $100 \%$ katolik, $100 \%$ Indonesia. Disana kepridian yang utuh, tidak terpecah, inilah yang sangat diharapkan dan sangat didukung dan dihidupi dalam negara, masyarakat Indonesia. (Bdk. H. Sumarjo, FIC-Komisi Pendidikan KWI - dan Catatan Nota Pastoral 2008, bdk. Nota Pastoral Tentang Pendidikan Katolik, Jakarta, 2009, hal.30-31).

Untuk mewujudkan cita-cita tersebut, maka para penyelenggara, pengelola dan pelaksana dunia Pendidikan Katolik dan Insan Pendidikan Katolik harus memahami, menghayati dan mengamalkan peranan hirarkis dalam karya kerasulan pendidikan. Hal-hal pokok yang perlu dipahami antara lain: Dokumen Gravissimum Educationis (GE) yang sangat gamblang berbicara tentang dunia pendidikan katolik, yang berarti pendidikan kepribadian manusia seutuhnya (manusia katolik, manusia Indonesia yang katolik), berarti juga bagi orang lain, kelompok lain yang mau berubah dan mau hidup dengan benar.

Ajaran Gereja yang tertuang dalam Konsili Ekumenis mempertimbangkan sangat pentingnya pendidikan dalam hidup manusia, serta dampak pengaruhnya yang makin besar atas perkembangan masyarakat zaman sekarang. Memang benarlah, pendidikan kaum muda, dalam situasi zaman sekarang menjadi lebih mudah, tetapi sekaligus juga lebih mendesak. Kemajuan-kemajuan yang mengagumkan di bidang teknologi dan penelitian ilmiah, begitu pula upaya-upaya komunikasi sosial yang baru, membuka peluang bagi peningkatan mutu karya pendidikan, secara khusus dalam hal karakter. Hak-hak asasi manusia, khususnya anak-anak serta orang tua, atas pendidikan dinyatakan dan dikukuhkan dengan dokumen-dokumen resmi. Menanggapi pesatnya laju pertambahan jumlah para siswa, dimana-mana sekolah-sekolah berlipatganda dan meningkat mutu, serta diciptakan lembaga-lembaga pendidikan lainnya. Metode-metode pendidikan dan pengajaran dikembangkan melalui eksperimen-eksperimen baru. Penulis menyodorkan tulisan/penggalan ini, karena sadar bahwa Gereja Katolik melalui ajaran resminya sangat konsen dengan pendidikan karakter yang membawa anak manusia, anak bangsa untuk hidup secara utuh (holistik) dalam hal kejasmanian (badaniah) dan kerohanian (religi) nya.

\section{Sekolah Katolik Menurut Kitab Hukum Kanonik (KHK, 803)}

Sekolah katolik, ialah suatu sekolah yang dibimbing oleh Kuasa gerejani yang berwenang atau oleh badan hukum gerejani publik atau pula yang diakui sebagai sekolah katolik (lembaga formal katolik) lembaga pendidikan melalui surat keputusan dari Kuasa gerejani. Di sini dimaksudkan: sekolah yang mendidik, mengajar dan mengasuh siswa/i yang ada dalam lembaga pendidikan resmi tersebut mengikuti proses pembentukan diri, akhlak, tabiat, dan kepribadian seutuhnya agar kelak menjadi manusia yang utuh (tujuan jangka panjang).

Pendidikan khususnya pendidikan moral, watak, tabiat mempunyai makna yang amat penting bagi kehidupan manusia dan mempunyai pengaruh yang makin besar terhadap kemajuan sosial. Karena itu Bunda Gereja yang kudus sangat berkepentingan untuk menjalankan perintah yang diterimanya dari Pendiri Ilahinya, yakni mewartakan misteri penyelamatan kepada semua orang dan memulihkan semua di dalam Kristus. Oleh karena itu, la harus mengusahakan kehidupan yang utuh baik dunia maupun akhirat. Karena itu kita bisa dalami beberapa artikel yang mengatakan tentang hal ini antara lain: 
Art. 1. Pendidikan pada umumnya. Semua dan setiap manusia mempunyai hak tidak tergugat atas pendidikan, sesuai dengan tujuan dan bakat serta latar belakang budaya. Pendidikan yang benar mengikhtiarkan pembinaan pribadi baik untuk tujuan akhir maupun untuk kepentingan masyarakat. Pendidikan juga harus membantu pengembangan bakat fisik, moral dan intelektual secara harmonis (karakter bangsa - penulis).

Proses pendidikan perlu memperhatikan nilai-nilai moral dan iman. Konsili menganjurkan, supaya putera-puteri Gereja (dan masyarakat yang mengenyam pendidikan katolik) dengan jiwa besar menyumbangkan jerih payah mereka di seluruh bidang pendidikan, terutama dengan maksud, agar buah-buah pendidikan dan pengajaran sebagaimana mestinya selekas mungkin terjangkau oleh siapapun di seluruh dunia.

Di sini berarti setiap umat kristiani diwajibkan untuk melakukan pendidikan - proses pendampingan kepribadian (watak, sifat, tabiat, fisik dan phsikis manusia-karakter) yang baik dan benar sesuai ajaran iman kita, dan terutama untuk kemajuan diri, kelompok dan masyarakat umumnya. Di sana unsur pembentuk kepribadian manusia sangat ditekankan dan sangat diprioritaskan. Dan inilah sebenarnya harapan untuk membangun, membentuk revolusi mental.

Tidak terlepas dari apa yang diinginkan dan sangat utama, kita tidak bisa melepaskan peran dari orang tua/ wali bagi perkembangan kepribadian atau karakter anak manusia. Untuk itu dalam KHK Kan 803, Art. 6 menulis tentang: "Kewajiban dan hak orang tua". Orang tua mempunyai kewajiban dan hak utama dalam mendidik anak. Maka mereka bebas memilih sekolah/pendidikan formal pembentukan karakter bagi anaknya. Negara wajib menjamin hak anak-anak untuk memperoleh pendidikan yang memadai, menjaga mutu pendidikan dan menerapkan prinsip subsidiaritas, dan kelanjutan pendidikan, pendampingan terutama karakter manusia/ anak, sangat dibutuhkan melalui pendidikan formal yakni sekolah.

KHK juga berkata pada Art.7 tentang pendidikan moral dan keagamaan di sekolah. Gereja (umatmasyarakat) berkewajiban untuk mengusahakan pendidikan moral dan keagamaan bagi semua putera-puterinya, termasuk yang berada di sekolah bukan Katolik, melalui kesaksian hidup para pendidik, kerasulan sesama siswa dan terutama melalui pelayanan para imam dan awam. Gereja memuji para penguasa dan masyarakat sipil dalam masyarakat yang menjamin kebebasan beragama bagi warganya dan pendidikan moral di sekolah/lembaga formal katolik sesuai dengan prinsip-prinsip moral dan religius yang dianut oleh keluarganya. Maka, Gereja sangat berkepentingan untuk mendampingi, menangani pendididikan karakter ini dalam lembaganya. Maka KHK sekali lagi berkata dalam tulisannya, dan tertuang pada Art. 8 tentang Sekolah Katolik/Lembaga pendidikan formal Katolik:

"seperti sekolah lainnya, sekolah Katolik mengejar tujuan-tujuan budaya dan pendidikan manusiawi. Tetapi ciri khasnya ialah menciptakan lingkungan hidup bersama yang dijiwai oleh semangat injil, kebebasan dan cinta kasih. Pengetahuan yang mereka peroleh mengenai dunia, kehidupan dan manusia juga harus disinari oleh iman, agar mereka menjadi ragi keselamatan bagi masyarakat".

Gereja berhak mendirikan dan mengurus segala macam sekolah pada semua tingkat. Guru, para pendidik memainkan peranan utama dalam melaksanakan visi dan misi sekolah Katolik. Oleh karena itu mereka perlu disiapkan secara sungguh-sungguh baik di bidang ilmu pengetahuan profan termasuk metodologi pendidikan maupun dalam hal iman atau keagamaan. Untuk itu sangat diharapkan para guru mempunyai hubungan cinta kasih dengan murid dan mempunyai semangat merasul. Dengan demikian para guru memberi kesaksian hidup tentang Kristus Sang Guru melalui teladan hidup mereka.

Hendaknya para guru bekerjasama dengan para orang tua agar dapat mendidik para siswa/anak didik dengan baik sesuai dengan minat, bakat dan kondisinya. Sekolah Katolik hendaknya memperhatikan para 
alumni. Konsili juga mengingatkan agar para orang tua Katolik sedapat mungkin menyekolahkan anaknya di sekolah Katolik dan atau lembaga pendidikan formal lainnya.

Untuk hal yang penting ini, maka Konsili sangat menganjurkan kepada para Gembala Gereja dan segenap umat beriman untuk membantu sekolah-sekolah Katolik/lembaga pendidikan katolik agar makin sempurna menjalankan tugasnya dalam dunia pendidikan terutama bagi kaum miskin, anak-anak yang kurang mendapatkan kasih sayang dalam keluarga atau masih jauh dari karunia iman, terutama karakter manusia (baca: terutama karakter bangsa).

Konsili mendorong kaum muda, anak bangsa untuk menyadari keluhuran tugas dan panggilan sebagai pendidik, terutama di daerah yang kekurangan guru. Konsili menyatakan syukur dan terima kasih kepada para imam, religius dan awam yang dengan semangat injili membaktikan diri dalam dunia pendidikan dan persekolahan. Konsili mendorong mereka agar tetap tekun dan setia dalam menjalankan tugas di dunia pendidikan demi pengembangan ilmu dan iman (karakter diri/bangsa/manusia) para siswa sehingga mereka menjadi kader yang unggul demi Gereja dan Bangsa.

Demikianlah isi dari Dokumen Konsili Vatikan II tentang pendidikan, yang mestinya menjadi acuan kerasulan Gereja di bidang pendidikan, dan sekaligus sebagai sarana ampuh untuk membina jati diri manusia, khususnya karakter bangsa/karakter diri yang sangat dibutuhkan, dibahas dan bahkan sangat diharapkan untuk merubah (revolusi) secara drastis demi kepentingan manusia itu sendiri. (Bdk. tulisan Jakarta, 22 November 2006, Pengurus Komdik KWI Periode 2006-2009).

\section{Pentingnya Pendidikan Karakter di Sekolah}

Dari pembahasan di atas dapat dilihat apa yang diharapkan Gereja dapat terealisasi melalui pendidikan karakter di sekolah. Hal ini dapat dilihat dari fungsi Pendidikan Karakter yang dapat disimpulkan dalam tiga hal: Pertama, fungsi pembentukan dan pengembangan potensi. Di sini Pembangunan karakter bangsa berfungsi membentuk dan mengembangkan potensi manusia atau warga negara Indonesia agar berpikiran baik, berhati baik, dan berperilaku baik sesuai dengan falsafah hidup Pancasila. Kedua, Fungsi Perbaikan dan Penguatan. Pembangunan karakter bangsa berfungsi memperbaiki dan memperkuat peran keluarga, satuan pendidikan, masyarakat, dan pemerintah untuk ikut berpartisipasi dan bertanggung jawab dalam pengembangan potensi warga negara dan pembangunan bangsa menuju bangsa yang maju, mandiri, dan sejahtera. Ketiga, Fungsi Penyaring. Pembangunan karakter bangsa berfungsi memilah budaya bangsa sendiri dan menyaring budaya bangsa lain yang tidak sesuai dengan nilai-nilai budaya dan karakter bangsa yang bermartabat. Ketiga fungsi tersebut dilakukan melalui: (1) Pengukuhan Pancasila sebagai falsafah dan ideologi negara, (2) Pengukuhan nilai dan norma konstitusional UUD 45, (3) Penguatan komitmen kebangsaan Negara Kesatuan Republik Indonesia (NKRI), (4) Penguatan nilai-nilai keberagaman sesuai dengan konsepsi Bhinneka Tunggal Ika, serta (5) Penguatan keunggulan dan daya saing bangsa untuk keberlanjutan kehidupan bermasyarakat, berbangsa, dan bernegara Indonesia dalam konteks global.

Pembangunan karakter bangsa bertujuan untuk membina dan mengembangkan karakter warga negara sehingga mampu mewujudkan masyarakat yang ber-Ketuhanan Yang Maha Esa, berkemanusiaan yang adil dan beradab, berjiwa persatuan Indonesia, berjiwa kerakyatan yang dipimpin oleh hikmat kebijaksanaan dalam permusyawaratan perwakilan, serta berkeadilan sosial bagi seluruh rakyat Indonesia.

Pembangunan Karakter Bangsa merupakan suatu gerakan nasional dengan tema membangun generasi Indonesia yang jujur, cerdas, tangguh, dan peduli. Ini berarti bangsa, masyarakat Indonesia sangat konsen untuk mengembangkan, wewajibkan serta menghidupkan karakter bangsa demi kemajuan kehidupan bangsa secara jasmani/badaniah dan rohani/religi. Untuk semakin memahami pendidikan karakter bangsa dalam rangka usaha 
menrevolusikan kegiatan/pelaksanaannya, maka kita terbawa dalam ruang lingkup yang pasti dan terukur atau terbatas. Untuk itu, kita bisa melihat dalam hal ruang lingkupnya.

Ruang lingkup sasaran pembangunan karakter bangsa yang dicita-citakan meliputi:

\section{Lingkup Keluarga}

Keluarga merupakan wahana pembelajaran dan pembiasaan karakter yang dilakukan oleh orang tua dan orang dewasa lain dalam keluarga terhadap anak sebagai anggota keluarga sehingga diharapkan dapat terwujud keluarga berkarakter mulia yang tercermin dalam perilaku keseharian. Proses itu dapat dilakukan melalui komunitas keluarga dan partisipasi keluarga dalam pengelolaan pendidikan dan pemberdayaan masyarakat. Keluarga merupakan lingkungan yang pertama dan utama di mana orang tua bertindak sebagai pemeran utama dan panutan bagi anak. Proses itu dapat dilakukan dalam bentuk pendidikan, pengasuhan, pembiasaan, dan keteladanan. Pendidikan karakter dalam lingkup keluarga dapat juga dilakukan kepada komunitas calon orang tua dengan penyertaan pengetahuan dan keterampilan, khususnya dalam pengasuhan dan pembimbingan anak. Sangat diharapkan secara terus menerus dan berkelanjutan. Tidak berhenti pada satu fase atau tahap, tetapi bergiat sampai anak memperoleh karakter yang benar dan tepat sesuai ajaran agama/imannya dan ajaran falsafah negara seutuhnya.

\section{Lingkup Satuan Pendidikan}

Satuan pendidikan merupakan wahana pembinaan dan pengembangan karakter yang dilakukan dengan menggunakan: (a) pendekatan terintegrasi dalam semua mata pelajaran, (b) pengembangan budaya satuan pendidikan, (c) pelaksanaan kegiatan kokurikuler dan ekstrakurikuler, serta (d) pembiasaan perilaku dalam kehidupan di lingkungan satuan pendidikan. Pembangunan karakter melalui satuan pendidikan dilakukan mulai dari pendidikan usia dini sampai pendidikan tinggi. Salah satu kunci keberhasilan program pengembangan karakter pada satuan pendidikan adalah keteladanan dari para pendidik dan tenaga kependidikan. Keteladanan bukan sekadar sebagai contoh bagi peserta didik, dengan kata-kata, melainkan teladan hidup sebuah contoh hidup demi menguatkan moral bagi peserta didik dalam bersikap dan berperilaku. Oleh karena itu, penerapan keteladanan di lingkungan satuan pendidikan menjadi prasyarat dalam pengembangan karakter peserta didik.

\section{Lingkup Pemerintahan}

Pemerintahan merupakan wahana pembangunan karakter bangsa melalui keteladanan penyelenggara negara, elite pemerintah, dan elite politik. Unsur pemerintahan merupakan komponen yang sangat penting dalam proses pembentukan karakter bangsa karena aparatur negara sebagai penyelenggara pemerintahan merupakan pengambil dan pelaksana kebijakan yang ikut menentukan berhasilnya pembangunan karakter pada tataran informal, formal, dan nonformal. Pemerintahlah yang mengeluarkan berbagai kebijakan dalam pelaksanaan pembangunan. Kebijakan pemerintah dalam berbagai seginya (termasuk kebijakan dalam bidang penyiaran atau media massa) harus mengacu pada pengarusutamaan pembangunan karakter bangsa.

4. Lingkup Masyarakat Sipil

Masyarakat sipil merupakan wahana pembinaan dan pengembangan karakter melalui keteladanan tokoh dan pemimpin masyarakat serta berbagai kelompok masyarakat yang tergabung dalam organisasi sosial kemasyarakatan sehingga nilai-nilai karakter dapat diinternalisasi menjadi perilaku dan budaya dalam kehidupan sehari-hari.

5. Lingkup Masyarakat Politik 
Masyarakat politik merupakan wahana yang melibatkan warga negara dalam penyaluran aspirasi dalam politik. Masyarakat politik merupakan suara representatif dari segenap elite politik dan simpatisannya. Masyarakat politik memiliki nilai strategis dalam pembangunan karakter bangsa karena semua partai politik memiliki dasar yang mengarah pada terwujudnya upaya demokratisasi yang bermartabat.

6. Lingkup Dunia Usaha dan Industri

Dunia usaha dan industri merupakan wahana interaksi para pelaku sektor riil yang menopang bidang perekonomian nasional. Kemandirian perekonomian nasional sangat bergantung pada kekuatan karakter para pelaku usaha dan industri yang di antaranya dicerminkan oleh menguatnya daya saing, meningkatnya lapangan kerja, dan kebanggaan terhadap produk bangsa sendiri.

\section{Lingkup Media Massa}

Media massa merupakan sebuah fungsi dan sistem yang memberi pengaruh sangat signifikan terhadap publik, khususnya terkait dengan pembentukan nilai-nilai kehidupan, sikap, perilaku, dan kepribadian atau jati diri bangsa. Media massa, baik elektronik maupun cetak memiliki fungsi edukatif atau pun nonedukatif bergantung dari muatan pesan informasi yang disampaikannya. Fungsi dan peran media massa dirasa makin penting dalam era globalisasi saat ini seiring dengan kemajuan teknologi komunikasi dan informasi. Berbagai informasi yang berasal dari berbagai sumber, baik dari dalam maupun luar negeri dengan mudah dapat diakses secara langsung oleh masyarakat. Dalam kondisi seperti ini, informasi yang bertentangan dengan nilai-nilai budaya bangsa akan membawa dampak negatif terhadap upaya pembentukan karakter. Pada gilirannya, hal ini akan dapat mengancam jati diri bangsa. Atas dasar ini, sudah seharusnya media massa selalu memberikan perhatian dan kepedulian dalam setiap pemberitaan dan penyiaran informasi agar secara bertanggung jawab memasukkan pesan-pesan edukatif terkait dengan substansi pembangunan karakter bangsa (Bdk. Pendidikan Karakter Bangsa, Pengembangan Pendidikan Karakter Bangsa Berkelanjutan (PPKBB)...dan Tentang PENDIDIKAN KARAKTER, Keuskupan Agung Ende dan Pastoral Sekolah KAE Ende, 2012), Pendidikan Nilai: Pilar Utama Kehidupan, Herman Embuiru Wetu, 2009, hal. 26. 28-30).

Pembangunan karakter bangsa dilakukan secara koheren melalui proses sosialisasi, pendidikan dan pembelajaran, pemberdayaan, pembudayaan, dan kerja sama seluruh komponen bangsa dan negara.Untuk itu mengutip apa yang ditawarkan oleh negara dalam tulisan/uraian tentang Karakter bangsa yang diharapkan, tertuang dalam Bab 3 Tentang Arah Serta Tahapan Dan Prioritas Pembangunan Karakter Bangsa Tahun 2010_2025.

\section{Arah dan Sasaran Pendidikan Karakter}

Pembangunan karakter bangsa diarahkan menjadi bagian yang tidak terpisahkan dari upaya pencapaian visi pembangunan nasional sebagaimana tertuang dalam Rencana Pembangunan Jangka Panjang Tahun 20052025, yaitu mewujudkan Indonesia sebagai bangsa yang maju, mandiri, dan adil sebagai landasan bagi tahap pembangunan berikutnya menuju masyarakat adil makmur dalam NKRI berdasarkan Pancasila dan UndangUndang Dasar Negara Republik Indonesia Tahun 1945.

Untuk mencapai visi tersebut, pembangunan nasional jangka panjang diarahkan untuk mengemban misi sebagai berikut.

Mewujudkan masyarakat Indonesia yang berakhlak mulia, bermoral, beretika, berbudaya dan berkeadaban; Mewujudkan bangsa yang berdaya saing untuk mencapai masyarakat yang lebih makmur dan sejahtera; Mewujudkan Indonesia yang demokratis, berlandaskan hukum, dan berkeadilan; 
Mewujudkan rasa aman dan damai bagi seluruh rakyat serta terjaganya keutuhan wilayah NKRI dan kedaulatan negara dari ancaman, baik dari dalam negeri maupun luar negeri;

Mewujudkan pembangunan yang lebih merata dan berkeadilan;

Mewujudkan Indonesia yang asri dan lestari;

Mewujudkan Indonesia sebagai negara kepulauan yang mandiri, maju, kuat, dan berbasiskan kepentingan nasional;

Mewujudkan Indonesia berperan penting dalam pergaulan dunia internasional.

Pembangunan karakter bangsa yang diemban pada misi pertama mengarahkan pada terwujudnya masyarakat berakhlak mulia, bermoral, beretika, berbudaya, dan beradab berdasarkan falsafah Pancasila. Hal ini mengandung arti memperkuat jati diri dan karakter bangsa melalui pendidikan yang bertujuan membentuk manusia yang bertakwa kepada Tuhan yang Maha Esa; mematuhi aturan hukum; memelihara kerukunan internal dan antarumat beragama; melaksanakan interaksi antarbudaya; mengembangkan modal sosial; menerapkan nilai-nilai luhur budaya bangsa; dan memiliki kebanggaan sebagai bangsa Indonesia dalam rangka memantapkan landasan spiritual, moral, dan etika pembangunan bangsa.

Secara eksplisit, keberhasilan pembangunan karakter bangsa ditandai dengan tercapainya sasaran sebagai berikut.

Terwujudnya karakter bangsa yang tangguh, kompetitif, berakhlak mulia, bermoral, bertoleran, bergotong royong, patriotik, dinamis, berbudaya, dan berorientasi Iptek berdasarkan Pancasila dan dijiwai oleh iman dan takwa kepada Tuhan Yang Maha Esa.

Makin mantapnya budaya bangsa yang tercermin dalam meningkatnya harkat dan martabat manusia Indonesia, serta menguatnya jati diri dan kepribadian bangsa.

Berdasarkan pemikiran ini, maka apa yang harus dilakukan? Menawarkan pendidikan karakter sebagai bagian dari revolusi mental, merupakan salah satu cara/ metode yang tampan dan segera mungin bahkan dengan kata revolusi, secepatnya, tepat dan teratur atau dikenal dengan motto: SMART (Specific, Measurable, Achievable, Realistic dan Timebond). Specific disini berarti sebuah gerakan revolusi pendidikan karakter harus spesifik yang berarti kekhasan/spesial dalam hal tabiat/sifat, kepribadian manusia. Miserable yang berarti bisa diukur dengan waktu, yang ditawarkan oleh negara RI jangka waktu 2005 sd 2025 (jangka waktu tertentu pembentukan karakter bangsa dapat dijangau, dapat tercapai. Achievable yang artinya dapat dicapai dan diukur sejauh mana pembentukan karakter yang diharapkan. Realistic, berarti realistik, riil, nyata yang disampaikan kepada manusia, anak bangsa untuk bisa merubah diri dalam segala hal (kepribadian). Timebond, berarti ada batas waktunya dan diukur dengan cara baik dan benar atau tanpa kepalsuan. Inilah yang sangat diharapkan ketika kita mau mendidik anak manusia Indonesia sebagai sebuah revolusi mental, atau gerakan untuk membentuk anak bangsa ini. (Bdk. Pendidikan Karakter Bangsa, Pengembangan Pendidikan Karakter Bangsa Berkelanjutan (PPKBB).

\section{Penutup}

Akhirnya, apa yang ditawarkan dalam tulisan sederhana, Penulis mengutip kata akhir dari kebijakan Negara sebagai tertera pada bagian berikut: "Kebijakan Nasional Pembangunan Karakter Bangsa 2010-2025 berisi latar belakang pentingnya pembangunan karakter bangsa; kerangka dasar pembangunan Karakter bangsa; arah, serta tahapan dan prioritas; strategi pembangunan karakter bangsa". 
Kebijakan Nasional Pembangunan Karakter Bangsa ini dimaksudkan sebagai acuan dalam merancang, mengembangkan, dan melaksanakan Rencana Aksi Nasional (RAN) Pembangunan Karakter Bangsa yang menggalang partisipasi aktif keluarga; satuan pendidikan; masyarakat; pemerintah; generasi muda; lanjut usia; media massa; pramuka; organisasi kemasyarakatan; organisasi politik; organisasi profesi; organisasi masyarakat pemberdayaan perempuan, lembaga swadaya masyarakat termasuk kelompok strategis seperti elite struktural, elite politik, wartawan, budayawan, pemuka agama, tokoh adat, dan tokoh masyarakat.

Keberhasilan pembangunan karakter bangsa, terutama revolusi mental menjadi sasaran utamanya diarahkan menjadi bagian yang tidak terpisahkan dari upaya pencapaian visi pembangunan nasional, yaitu mewujudkan Indonesia sebagai bangsa yang tangguh, kompetitif, berakhlak mulia, bermoral, bertoleran, bergotong royong, patriotik, dinamis, berbudaya, dan berorientasi Ipteks berdasarkan Pancasila dan dijiwai oleh iman dan takwa kepada Tuhan Yang Maha Esa.

Mengingat penting dan luasnya cakupan pembangunan karakter bangsa dalam rangka mewujudkan masyarakat yang ber-Ketuhanan yang Maha Esa, berkemanusiaan yang adil dan beradab, berjiwa persatuan Indonesia, berjiwa kerakyatan yang dipimpin oleh hikmat kebijaksanaan dalam permusyawaratan perwakilan, serta berkeadilan sosial bagi seluruh rakyat Indonesia, maka diperlukan komitmen dan dukungan sehabishabisnya dari lembaga penyelenggara negara, dunia usaha dan industri, masyarakat, keluarga, media massa dan pemangku kepentingan lainnya, lembaga pendidikan formal, lembaga pendidikan non formal untuk menyusun program kerja dan mengkoordinasikan dengan pihak terkait agar terjadi sinergi yang kokoh untuk mewujudkan Indonesia yang lebih baik.

Penulis cuma menawarkan hal yang sangat sedikit dalam pengembangan karakter bangsa sebagai sebuah revolusi, perubahan cepat tanpa merugikan siapapun dalam tulisan ini. Secara khusus penulis mengangkat apa yang diajarkan dalam ajaran Katolik yang tertuang dalam Dokumen resminya Dokumen Konsili Vatikan II dan Kitab Hukum Kanoki (KHK), dan dikembangkan lagi sesuai pengalaman, pemikiran dan pendampingan Penulis selama beberapa tahun tentang karakter bangsa. Dan bagaimana karakter bangsa ini segera dikembangkan. Tidak lain hanyalah mulai dan mulai dari sekarang ini dan secara menyeluruh/holistik oleh kita bangsa, masyarakat Indonesia sendiri.

\section{Kepustakaan}

Kamus besar Bahasa Indonesia, Departemen Pendidikan dan Kebudayaan - Balai Pustaka- Jakarta, 1988.

Dokumen Konsili Vatikan II, Gravissimum Educationis. Obor, Jakarta, 1993

Nota Pastoral Tentang Pendidikan, Lembaga Pendidikan Katolik: "Media Pewartaan Kabar Gembira, Unggul dan Lebih Berpihak Kepada Yang Miskin.”

Pendidikan Nilai: Pilar Utama Kehidupan, RD. Herman Embuiru Wetu, 2009.

Pendidikan Karakter Bangsa, Pengembangan Pendidikan -Karakter Bangsa Berkelanjutan (PPKBB), Teks manual, Kupang, 2013.

Teks Manual, Materi Seminar dan Pelatihan Tentang Pendidikan Karakter, Keuskupan Agung Ende dan Pastoral Sekolah KAE Ende, 2012. 
